\title{
APPLYING SCHMIDT-HAMMER EXPOSURE-AGE DATING (SHD) TO EVALUATE THE AGE OF PERIGLACIAL AND PARAGLACIAL FEATURES IN SOUTHERN NORWAY
}

DOI: http://dx.doi.org/10.18509/GBP.2018.18

UDC: 551.4.01:551.435.4(481)

\author{
Marr Philipp \\ Löffler Jörg \\ University of Bonn, Department of Geography, Germany
}

\begin{abstract}
Schmidt-hammer exposure-age dating (SHD) was performed on various talus derived landforms along a west-east transect in southern Norway. SHD provides useful information on the timing of formation and stabilization of periglacial and paraglacial landforms. These landforms are often associated to be geomorphological footprints of climatic cooling during the late Quaternary and the Holocene. The landform ages from the western location show that those landforms reacted more sensitively to climatic fluctuations, as many of periglacial landforms were re-mobilized and stabilized in the late Holocene. This is in contrast to the eastern study area, where most of the landforms stabilized in the late Quaternary. The estimated SHD ages show that the landforms in the eastern study area were not re-mobilized during several cold climate periods following the last deglaciation. All landforms investigated appear to be relict without recent process dynamics. We explain this by the sufficient moisture supply which enhances processes responsible for periglacial landforms formation and re-mobilization in the maritime western fjord region.
\end{abstract}

Keywords: Schmidt-hammer exposure-age dating (SHD); periglacial and paraglacial landforms; Holocene and late Quaternary climatic variations; Scandinavia

\section{INTRODUCTION}

The glaciation history of Scandinavia, particularly in southern Norway, is discussed since about 150 years [3], [21]. The knowledge of the vertical dimension of the ice sheet during the Last Glacial Maximum (LGM) can reveal important information on paleoenvironmental factors as sea-level changes, atmospheric and oceanic circulation, (de)glaciation patterns, ice sheet erosion and landscape evolution [7], [27]. Periglacial and paraglacial coarse rock landforms, including moraines, pronival ramparts or rock glaciers may provide useful insights into the connectivity of climatic changes and landform evolution [26]. Those landforms play an important role concerning the reconstruction of the characteristics and vertical extent of former ice sheets during the last Weichselian glaciations as well as following deglaciations [21] and they can assist to portray the regional climate history since the late Quaternary [26], [29]. Furthermore, by determining landform ages it is possible to better understand their geomorphic process activity and to explore their palaeoclimatic implications [29].

Weathering strongly influences the physical and chemical properties of rock surfaces. The degree of weathering reflects the length of weathering exposure, which influences rock hardness. Rock hardness is used to estimate the time of rock surface exposure and 
can be measured by using the Schmidt hammer [4]. Originally, the Schmidt hammer was developed to test the hardness of concrete in situ and has been used for geomorphological research in different applications in the past decades [8]. It has been widely applied as a relative dating tool to determine surface exposure of glacial and periglacial talus derived landforms as moraines [18], rock glaciers [10] and periglacial trimlines [2]. Schmidthammer exposure-age dating (SHD) is a recently developed approach, which gives the opportunity to robustly and numerically estimate landform ages by establishing a local linear high-precision calibration curve with two control points of known age [14]. The assumed linear R-value age relationship in this approach is sustained by SHD [26] and rock weathering [5] studies. SHD age estimates are generally in good agreement with ages obtained by terrestrial cosmogenic nuclide dating [14] and radiocarbon dating [1]. This technique was already successfully applied in different parts of Norway [1], [24]. Most Schmidt hammer studies in Norway were carried out in Jotunheimen and surroundings. In contrast, the western fjord area of central Norway is a relatively poorly studied region, we therefore aim attention to this region in this paper. As the lithology in the western fjord area is largely consistent, it appears to be promising to apply this cost effective and easily applicable method in a wide area in the future.

The aims of our study are fourfold: (1) to determine landform ages of peri- and paraglacial landforms by local calibration curves for different parts of southern Norway, (2) to find indications of evolution, stabilization and development of landforms, (3) to explore differences or similarities between landforms in the western and eastern part of southern Norway and (4) to link those information to changing climate since the late Quaternary from other regions.

\section{MATERIAL \& METHODS}

We applied SHD on a variety of talus derived periglacial and paraglacial landforms in southern Norway. The western study area is located in Opplendskedalen around Dalsnibba (1476 $\mathrm{m}$ a.s.l.) in the western fjord region, the other site is located in Ottadalen on Blåhø (1618 m a.s.1.) in the south-eastern part of Norway (Figure 1). These two areas are particularly interesting due their climatic gradient due to the Scandes, acting as an orogenetic boundary leading to annual precipitation of $1500-2000 \mathrm{~mm} / \mathrm{yr}$ in the west and $300 / 400 \mathrm{~mm} / \mathrm{yr}$ in valleys in the east. The bedrock around Dalsnibba largely consists of granitic gneiss, whereas the summit of Blåh $\varnothing$ is dominated by meta-conglomerate and meta-sandstone at higher and lower slopes, respectively [25]. Previous studies have shown that gneissic bedrock is suitable for measuring the degree of surface rock weathering [14].

There has been a long lasting controversial debate concerning the glaciation history of Blåhø. Two modes were among the most discussed during the last glaciation, the coverage by cold-based ice or an ice-free summit area [7]. The deglaciation history of Opplendskedalen remains ambiguous, there are no numerical ages available of the area known to the authors. The sparse information on deglaciation are mostly based on large scale deglaciation models [11] or swath bathymetric data [12]. 


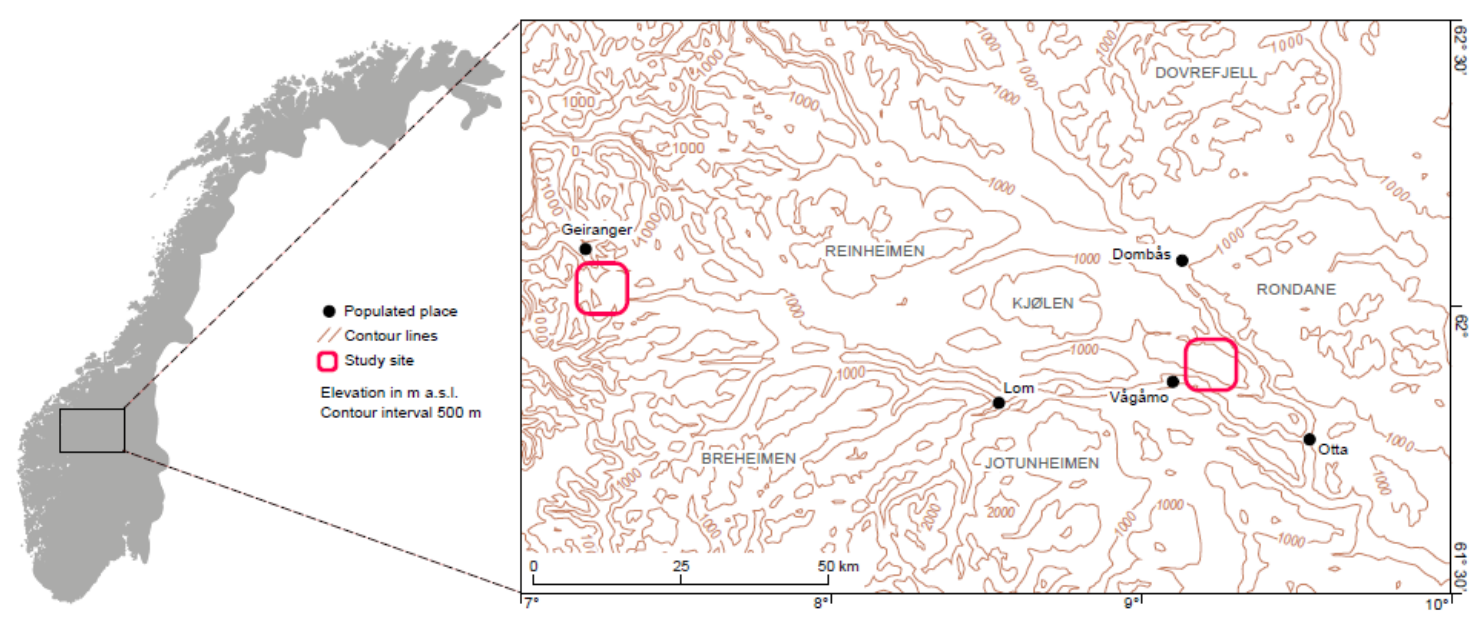

Figure 1: Study locations in southern Norway with Dalsnibba in proximity to Geiranger in the west and Blåhø, next to Vågåmo in the east [9].

The investigated landforms (Figure 2) include one blockfield (1562 m a.s.1.), sorted polygons (1450 $\mathrm{m}$ a.s.1.), one blockstream and one rock-slope failure ( $\sim 550 \mathrm{~m}$ a.s.l.) at Blåhø. At Dalsnibba we investigated one pronival rampart (1198 m a.s.l.); one moraine (1166 $\mathrm{m}$ a.s.1.), and a rock-slope failure with an upper and lower part (1311-1250 $\mathrm{m}$ a.s.1.). In the following, we will focus on selected landforms located in the western study area (Figure 2 a-c).
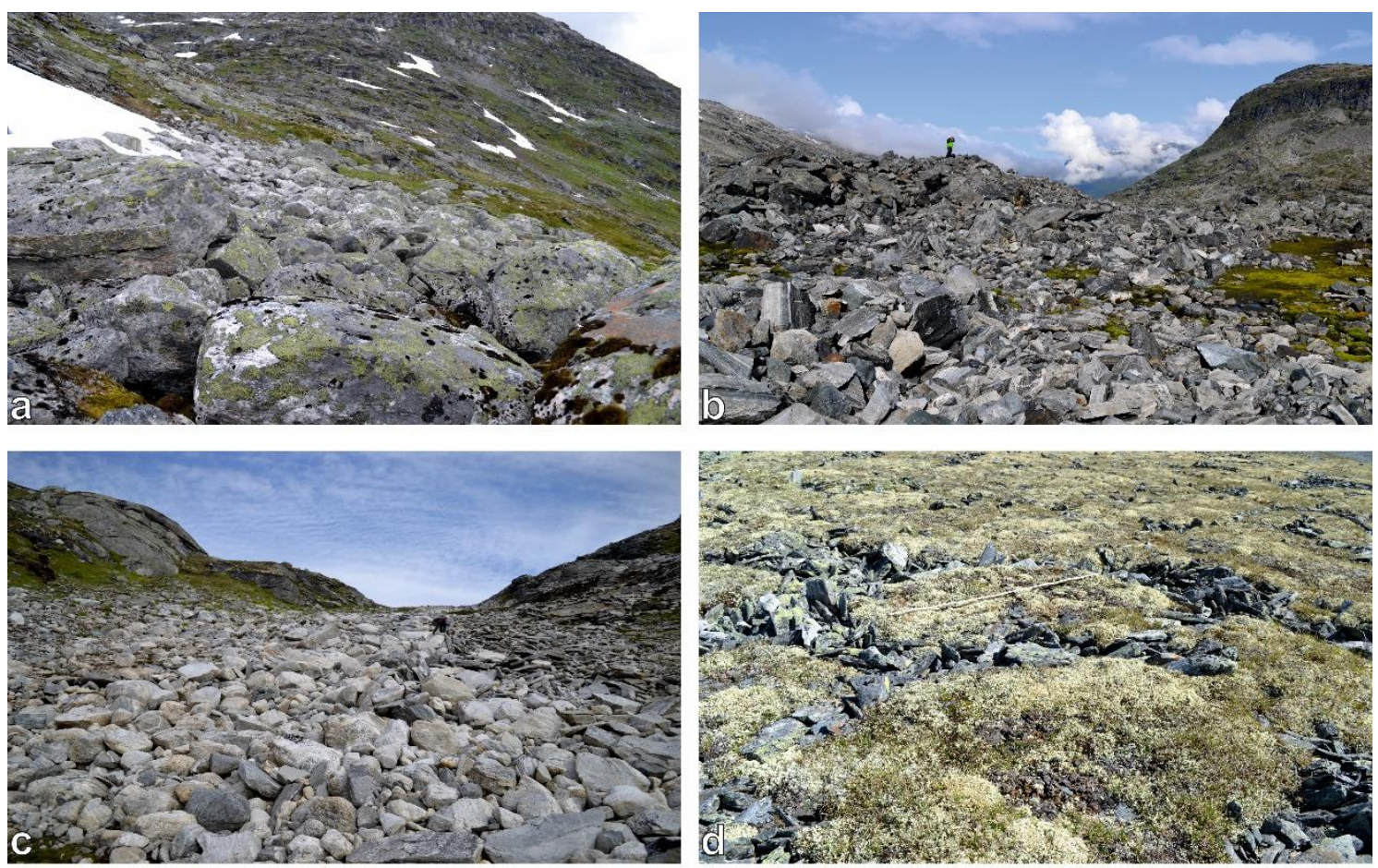

Figure 2: (a) View on the pronival rampart (west) in direction north-east.

(b) View on the moraine towards north-west. Note the person for scale.

(c) Up-valley view towards north from the lower part of the rock-slope failure.

(d) View on sorted polygons in the eastern study area towards west. The pole is $2 \mathrm{~m}$ long. 
In this study a calibrated N-Type electronic RockSchmidt (2.207 Nm) was used, measuring the rebound velocity of a spring loaded piston held on a rock surface [22]. The gained rebound (R-) values are connected to the elastic properties of the surface and its compressive strength [20], [28]. The results are interpreted on the basis that rock surfaces get more weathered with time, reducing surface hardness [18], [20]. Accordingly, high R-values are obtained from hard (fresh) surfaces [18], [20].

There is no standard measurement design, different approaches have been used in the past [8], [24]. We measured 100 boulders from each landform at minimum, with two blows per boulder. This design was chosen due to generate representative sample size [24] and due to comparable studies in the area [14]. The large number of blows increases the statistical significance, lowers the probability of outliners, the impact of lithological heterogeneities and micro weathering [18], [28]. Only stable boulders with an $a b$ axis longer than $30 \mathrm{~cm}$ were considered. The measurements were carried out at near horizontal and dry surfaces. Possible sources of error as visual structural rock weaknesses, rock edges and moss or lichen cover had been avoided.

The generated data were statistically processed using $\mathrm{R}$ statistic software. Histograms were plotted to check the value distribution, as bimodal distribution could be associated with relocation processes or different exposure history [28]. The standard statistical analysis comprised the calculation of the standard mean, standard error of the mean (SEM) at 95\% confidence interval, median, skewness and test of normality (ShapiroWilk-Test) [24]. The interpretation is based on the premise that sites with an overlap of the SEM values range are of equal age [24], [28].

Based on young and old control points of each study region calibration equations were calculated, each based on its local lithology. The young control points from each study site were obtained from boulders excavated by road constructions. Due to the lack of dated material around Dalsnibba, the old control point from the west was derived from a proximate bedrock locality from Loenvatnet with an age of $\sim 10 \mathrm{ka}$ [17] and comparable lithology (augen gneiss). The old control point from the eastern study area was generated by bedrock surfaces from known age [7]. A detailed description for calculating the linear high-precision age calibration curve is presented by [26].

\section{RESULTS}

The Schmidt hammer results of the control sites differ about 20 to 30 units between the young and old control point at each site. Both young control points exhibit half of the variability than both old control points. The linear calibration curve was derived from each the young and old control point from the western and the eastern study area.

The visual appearance of landforms indicated no post-depositional disturbance or signs of recent process dynamics. This is supported by extensive moss and lichen covers. The mean R-values of the selected landforms range between $55.89 \pm 1.53$ and $62.60 \pm 1.38$ and display a relatively low $95 \%$ confidence interval (Table 1). The landforms studied share negative skewness. The overlapping 95\% confidence intervals of the pronival rampart and the moraine permits to group them together. We also grouped together the upper and lower part of the rock-slope failure as their 95\% confidence intervals overlap as well. All landforms fail the Shapiro-Wilk test for normality.

The estimated SHD ages are summarized in Table 1 and were calculated from the calibration curve for the western study area. The ages range from $4979 \pm 589$ years of the upper part of rock-slope failure to $2662 \pm 526$ years of the moraine at the foot of 
Dalsnibba. The pronival rampart and the moraine share the same age, the two parts of the rock-slope failure show indistinguishable ages.

Table 1: Selected Schmidt hammer mean R-values, standard deviation, skewness, SHD ages and $n$ for the landforms studied. Each SHD age has a 95\% confidence interval $(\mathrm{Ct})$ derived from the sampling error of the landform sample $(\mathrm{Cs})$ and the error of the calibration curve $(\mathrm{Cc})$.

\begin{tabular}{lcccccc}
\hline Landform & $\begin{array}{c}\text { Mean } \pm \mathbf{9 5} \\
\mathbf{C I}^{\mathbf{a}}\end{array}$ & $\boldsymbol{\sigma}$ & Skewness & $\begin{array}{c}\text { SHD age } \\
\text { (years) }\end{array}$ & $\boldsymbol{C}_{\boldsymbol{t}}$ (years) & $\begin{array}{c}\text { Boulders } \\
(\mathbf{n})\end{array}$ \\
\hline pronival rampart & $59.89 \pm 0.65$ & 7.39 & -0.29 & 3598 & \pm 330.0 & 250 \\
$\begin{array}{l}\text { moraine } \\
\text { rock-slope }\end{array}$ & $62.60 \pm 1.38$ & 9.92 & -1.03 & 2662 & \pm 526.9 & 100 \\
$\begin{array}{l}\text { failure (u) } \\
\text { rock-slope }\end{array}$ & $55.95 \pm 1.52$ & 10.92 & -0.50 & 4979 & \pm 589.0 & 100 \\
failure (l) & $55.89 \pm 1.53$ & 10.98 & -0.75 & 4958 & \pm 591.9 & 100 \\
\hline
\end{tabular}

${ }^{a}$ Mean of R-values with $95 \%$ confidence intervals $(\alpha=0.05)$.

u: upper site; l: lower site.

The frequency distributions (Figure 3) largely show comparable characteristics between the landforms. The histograms of the pronival rampart and the moraine show a narrow tail and few boulders with low R-values within the population. The mode of distribution of both landforms is somewhat higher of those of both rock-slope failure parts. Both rockslope failure parts show a higher amount of more weathered boulders in their frequency distribution. Further, the lower part of the rock-slope failure shows a more plateau like distribution.

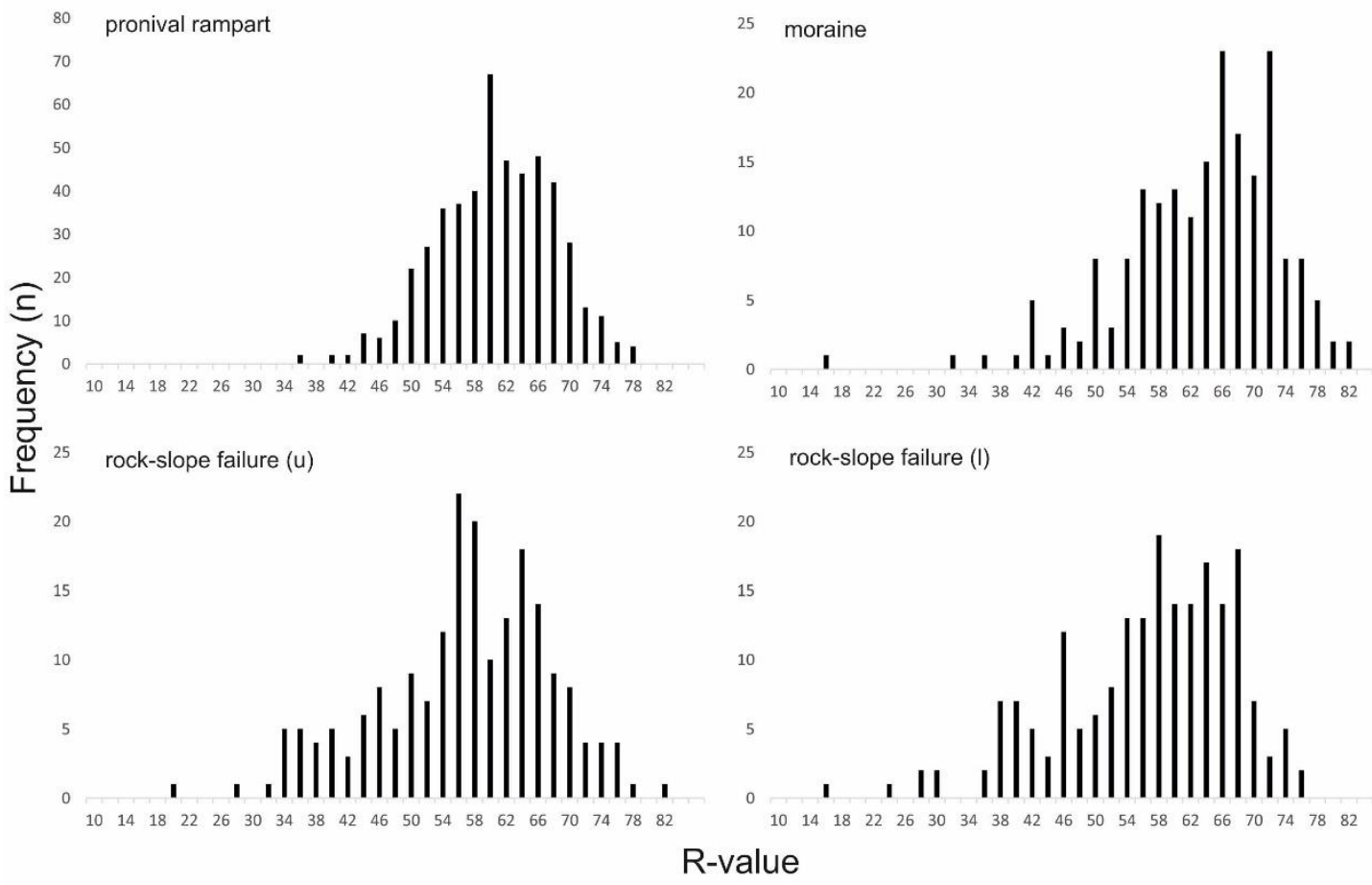

Figure 3. Frequency distributions of Schmidt hammer R-values from selected investigated landforms.

\section{DISCUSSION AND CONCLUSION}

The high R-value variability between the young and old control points reflects the longterm weathering exposure [29]. Yielding the young control points from construction sites 
is not ideal due to subsurface weathering which is occurring to an unknown extent [29]. However, these sites might more likely represent original conditions as boulders (e.g. from bedrock headwalls) become exposed for the first time [16].

The gained exposure ages ranging from $4979 \pm 589$ years of the upper part of rock-slope failure to $2662 \pm 526$ years of the moraine reflect the relict and inactive status of landforms investigated. All landforms became stable during the mid-Holocene Neoglaciation following the Holocene Thermal Maximum (HTM). This is sustained by the missing indications of post-depositional disturbance. Because of this, we interpret our SHD ages as maximum age estimates since the time when landforms stabilized. Furthermore, SHD ages give minimum estimates for the time of the beginning of landform formation, as there were older boulders beneath the surface boulders [26]. This is also sustained by the negative skewness pointing to a long-term landform formation history, to a later reactivation of landforms and to the final stabilization documented by our SHD ages.

Connecting our SHD ages with periods of cold climatic conditions partly validates the notion that talus derived peri- and paraglacial landforms are connected to cold climates [26]. Landforms investigated in the western study area stabilized during the midHolocene Neoglaciation which was characterized by decreasing temperatures and declining moisture supply. The SHD moraine age indicates it stabilized during the Smørstabbtindan IV cold event (2.55-3.20 ka), identified by [13] in Jotunheimen. Further, our moraine age corresponds well to other late Holocene moraine ages from southern Norway [1]. The frequency distributions of the moraine are comparable to those obtained by other moraines [23]. Despite the general ice free conditions in the area during the estimated age of stabilization, it remains possible that a small ice cap developed at the foot of the valley head which may be responsible for moraine formation.

The pronival rampart most likely stabilized during the end of Smørstabbtindan III (3.85$4.75 \mathrm{ka}$ ). However, pronival rampart ages cannot easily be linked to climate conditions, as they mostly develop continuously with varying intensity [15]. The skewness and the relatively young age of the rampart supports the concept of continuous buildup of the landform throughout the Holocene. Bearing in mind the nature of the histogram and the rather narrow confidence interval, the continuous buildup must have occurred in a short period of time.

The rock-slope failure histograms generally show a relatively high amount of more weathered boulders within the population (Figure 3). As there is no pronounced single peak in both rock-slope failure frequency distributions, the landforms most likely developed of a longer time scale, with several rock-fall events over $\sim 1200$ years. The timing of the eastern rock-slope coincides with the end of the HTM, the 95\% confidence interval overlaps also with the beginning of the Smørstabbtindan III. Our results tackle the concept that rock-slope failures often occur shortly after deglaciation [6]. Generally, our rock-slope failure ages support findings of other gravitational processes in southern Norway showing intensified (rock-)avalanche activity during the second half of the Holocene [12]. Rock-slope failures can also be connected to warmer climates, when snow melt and permafrost degradation are enhanced [19]. Prolonged warm periods following the LGM probably lead to permafrost degradation and weakening of the slope [19]. In concert with [19], we consider our rock-slope failures to have occurred during the HTM, when water pressures increased during snow melt, permafrost degradation and heavy precipitation. 
The generated SHD ages of peri- and paraglacial landforms in east and west of south Norway show significant differences in timing of formation, stabilization and remobilization. Whereas landforms in the east were most likely formed prior the LGM Deglaciation, stabilized during cold phases closely following Deglaciation and were not re-mobilized by cold climate periods since then, the landforms in the west reacted differently. The western landforms seem to be more sensitive to climatic changes which is probably connected to the higher moisture supply enhancing frost sorting and together with declining temperatures periglacial processes and landform formation and probably the build-up of small ice caps. This supports the notion that maritime, temperate glaciers have a rather short response time to climatic changes of 15-60 years [13].

Here, we present valuable insights in the interaction between landform evolution in connection to climatic changes. This study gives first indications about the geomorphic footprint differences of late Quaternary and Holocene cold events in the western fjord region in southern Norway. Following conclusions can be drawn from the present study:

1. Landforms studied appear to be relict with no recent process dynamics.

2. Landforms investigated in the western fjord region stabilized during the Neoglaciation following the Holocene Thermal Maximum.

3. Landforms in the eastern study area stabilized significantly earlier and were not remobilized by subsequent Holocene cold events.

4. The western landforms seem to react more sensitively to changing climatic conditions. We explain this by the sufficient moisture supply which enhances processes responsible for periglacial landforms formation.

\section{ACKNOWLEDGEMENTS}

We are thankful to Jenny Müller and Claire Pfalzner-Gibbon who contributed during the field work. This study was financed by the Friedrich-Ebert-Stiftung.

\section{REFERENCES}

[1] Aa AR, Sjåstad JA (2000): Schmidt hammer age evaluation of the moraine sequence in front of Bøyabreen, western Norway. Norsk Geologisk Tidsskrift, Vol. 80, No. 1, pp. $27-32$.

[2] Ballantyne CK, McCarroll D, Nesje A, Dahl SO (1997): Periglacial trimlines, former nunataks and the altitude of the last ice sheet in Wester Ross, northwest Scotland. Journal of Quaternary Science, Vol. 12, No. 3, pp. 225-238.

[3] Blytt A (1876): Immigration of the Norwegian Flora. Alb. Cammermeyer, Christiania.

[4] Černá B, Engel Z (2011): Surface and sub-surface Schmidt hammer rebound value variation for a granite outcrop. Earth Surface Processes and Landforms, Vol. 36, No. 2, pp. 170-179.

[5] Colman SM (1981): Rock-weathering rates as functions of time. Quaternary Research, Vol. 15, No. 3, pp. 250-264.

[6] Cruden DM, Hu XQ (1993): Exhaustion and steady state models for predicting landslide hazards in the Canadian Rocky Mountains. Geomorphology, Vol. 8, No. 4, pp. 279-285.

[7] Goehring BM, Brook EJ, Linge H, Raisbeck GM, Yiou F (2008): Beryllium-10 exposure ages of erratic boulders in southern Norway and implications for the history of the Fennoscandian Ice Sheet. Quaternary Science Reviews, Vol. 27, No. 3-4, pp. 320-336.

[8] Goudie AS (2006): The Schmidt Hammer in geomorphological research. Progress in Physical Geography, Vol. 30, No. 6, pp. 703-718. 
[9] Hein N, Feilshauer H, Finch O-D, Schmidtlein S, Löffler J (2014): Snow cover determines the ecology and biogeography of spiders (araneae) in alpine tundra ecosystems. Erdkunde, Vol. 68, No. 3, pp. 157-172.

[10] Humlum O (1998): Rock glaciers on the Faeroe Islands, the north Atlantic. Journal of Quaternary Science, Vol. 13, No. 4, pp. 293-307.

[11] Hughes ALC, Gyllencreutz R, Lohne ØS, Mangerud J, Svendsen JI (2016): The last Eurasian ice sheets - a chronological database and time-slice reconstruction, DATED-1. Boreas, Vol. 45, No. 1, pp. 1-45.

[12] Longva O, Blikra LH, Dehls JF (2009): Rock avalanches: distribution and frequencies in the inner part of Storfjorden, Møre og Romsdal County, Norway. Report, Geological Survey of Norway.

[13] Matthews JA, Dresser PQ (2008): Holocene glacier variation chronology of Smørstabbtindan massif, Jotunheimen, southern Norway, and the recognition of century- to millennial-scale European Neoglacial Events. The Holocene, Vol. 18, No. 1, pp. 181-201.

[14] Matthews JA, Owen G (2010): Schmidt hammer exposure-age dating: developing linear agecalibration curves using Holocene bedrock surfaces from the Jotunheimen-Jostedalsbreen regions of southern Norway. Boreas, Vol. 39, No. 1, pp. 105-115.

[15] Matthews JA, Wilson P (2015): Improved Schmidt-hammer exposure ages for active and relict pronival ramparts in southern Norway, and their palaeoenvironmental implications. Geomorphology, Vol. 246, pp. 7-21.

[16] Matthews JA, Winkler S, Wilson P (2014): Age and origin of ice-cored moraines in Jotunheimen and Breheimen, southern Norway: insights from Schmidt-Hammer exposure-age dating. Geografiska Annaler: Series A, Physical Geography, Vol. 96, No. 4, pp. 531-548.

[17] Matthews JA, Owen G, Winkler S, Vater AE, Wilson P, Mourne RW, Hill JL (2016): A rock-surface microweathering index from Schmidt hammer R-values and its preliminary application to some common rock types in southern Norway. Catena, Vol 143, pp. 35-44.

[18] McCarroll D (1989): Potential and Limitations of the Schmidt Hammer for Relative-Age Dating: Field Tests on Neoglacial Moraines, Jotunheimen, Southern Norway. Arctic Alpine Research, Vol. 21, No. 3, pp. 268-275.

[19] McColl ST (2012): Paraglacial rock-slope stability. Geomorphology, Vol. 153-154, pp. 116.

[20] Nesje A, McCarroll D, Dahl SO (1994): Degree of rock surface weathering as an indicator of ice-sheet thickness along an east-west transect across southern Norway. Journal of Quaternary Science, Vol. 9, No. 4, pp. 337-347.

[21] Nesje A, Dahl SO, Linge H, Ballantyne CK, McCarroll D, Brook EJ, Raisbeck GM, Yiou F (2007): The surface geometry of the Last Glacial Maximum ice sheet in the Andøya-Skånland region, northern Norway, constrained by surface exposure dating and clay mineralogy. Boreas, Vol. 36, No. 3, pp. 227-239.

[22] Proceq (2014): Operating instructions RockSchmidt and Rocklink. Proceq SA, Schwerzenbach.

[23] Shakesby RA, Matthews JA, Winkler S (2004): Glacier variations in Breheimen, southern Norway: relative-age dating of Holocene moraine complexes at six high-altitude glaciers. The Holocene, Vol. 14, No. 6, pp. 899-910.

[24] Shakesby RA, Matthews JA, Owen G (2006): The Schmidt hammer as a relative-age dating tool and its potential for calibrated-age dating in Holocene glaciated environments. Quaternary Science Reviews, Vol. 25, No. 21-22, pp. 2846-2867.

[25] Tveten E, Lutro O, Thorsnes T (1998): Geologisk kart over Norge, 1:250.000. Norges Geologiske Unders $ø$ kelse, Trondheim. 
[26] Wilson P, Matthews JA (2016): Age assessment and implications of late Quaternary periglacial and paraglacial landforms on Muckish Mountain, northwest Ireland, based on Schmidt-hammer exposure-age dating (SHD). Geomorphology, Vol. 270, pp. 134-144.

[27] Winguth C, Mickelson D, Larsen E, Darter JR, Moeller CA, Stalsberg K (2005): Thickness evolution of the Scandinavian Ice Sheet during the Late Weichselian in Nordfjord, western Norway: evidence from ice-flow modeling. Boreas, Vol. 34, No. 2, pp. 176-185.

[28] Winkler S (2009): First attempt to combine terrestrial cosmogenic nuclide (10Be and Schmidt hammer relative-age dating: Strauchon Glacier, Southern Alps, New Zealand. Central European Journal of Geosciences, Vol. 1, No. 3, pp. 274-290.

[29] Winkler S, Matthews JA, Mourne RW, Wilson P (2016): Schmidt-hammer exposure ages from periglacial patterned ground (sorted circles) in Jotunheimen, Norway, and their interpretative problems. Geografiska Annaler: Series A, Physical Geography, Vol. 98, No. 3, pp. $265-285$. 